\title{
Larutan Pembersih Periuretra Sebelum Pemasangan Kateter Urin Menetap: Literature Review
}

\author{
Awaluddin ${ }^{1}$, Nursiswati ${ }^{2}$ \\ ${ }^{1}$ STIKes Tengku Maharatu, Pekan Baru, Riau, ${ }^{2}$ Fakultas Keperawatan Universitas Padjadjaran \\ E-mail: awaluddinhasan@yahoo.com
}

\begin{abstract}
Abstrak
Pemasangan kateter urin menetap pada pasien baru di rumah sakit adalah 23,2\% setiap bulan. Delapan puluh persen kejadian infeksi saluran kemih disebabkan oleh kateter urin menetap yang tidak aseptik. Kematian akibat infeksi ini adalah 32\% dari seluruh kasus infeksi nosokomial. Penggunaan larutan pembersih periuretra sebelum pemasangan kateter urin menetap dalam mengurangi infeksi saluran kemih kurang memadai. Metode yang digunakan adalah literature review, dengan pencarian pada database CINAHL, proquest, dan google scholar yang dipublikasikan dari tahun 1995 sampai dengan 2013. Kata kunci yang digunakan meliputi catheterization, indwelling urinary catheter, bacteriuria, meatal atau periurethral cleaning, urinary tract infection, dan nursing. Dua puluh lima literatur yang berkaitan didapatkan. Larutan yang umum digunakan adalah air kran, air steril, larutan antiseptik, dan salin normal. Tidak terdapat perbedaan yang signifikan secara statistik antara kejadian infeksi saluran kemih dengan penggunaan air kran dibandingkan dengan povidone-iodine $10 \%$ atau chlorhexidine $0.1 \%$. Hal yang sama juga ditemui saat pengunaan air steril dibandingkan dengan povidone-iodine atau chlorhexidine gluconate $10 \%$ atau $0.05 \%$, saat penggunaan air dan sabun, busa pembersih kulit, povidone-iodine $10 \%$, dan salin normal. Air steril adalah larutan hipotonik, tidak mahal, dan tidak mengiritasi kulit. Salin normal juga lebih murah dan kurang mengiritasi kulit. Larutan antiseptik cukup mahal, dapat mengiritasi kulit, dan memiliki efek samping alergi atau toksik. Sabun memiliki sedikit kadar antiseptik dan relatif murah. Larutan pembersih periuretra sebelum pemasangan kateter yang dapat digunakan adalah air kran, air steril, larutan antiseptik, salin normal, dan air dan sabun. Diperlukan penelitian selanjutnya tentang penggunaan air steril atau salin normal.
\end{abstract}

Kata kunci: Infeksi saluran kemih, kateter urin menetap, larutan pembersih periuretra.

\section{Periurethral Cleaning Solution Prior to Indwelling Urinary Catheter Insertion: A Literature Review}

\begin{abstract}
Monthly, $23.2 \%$ of new patients in hospital had an indwelling urinary catheter, and $80 \%$ of them had urinary tract infections. Data showed that this infection was contributed to $32 \%$ of death in nosocomial infection cases. Using the periurethral cleaning solution before the insertion of indwelling catheter to reduce urinary tract infections are still debated. This literature review used some databases such as CINAHL, proquest and google scholar that published between 1995 and 2013. Key words included catheterization, indwelling urinary catheter, bacteriuria, meatal or periurethral cleaning, urinary tract infection, and nursing. This study reviewed 25 appropriate literatures. The solution were tap water, sterile water, antiseptic solution, and normal saline. Statistically, there was no differences of incidences of urinary tract infection when tap water solution compared with povidone-iodine or chlorhexidine $0.1 \%$ as well the use of sterile water compared with povidone-iodine or chlorhexidine gluconate $10 \%$ or $0.05 \%$, water and soap, skin cleansing foam, povidone iodine, and normal saline. Sterile water is an inexpensive hypotonic solution and does not irritate the skin. Normal saline is also less expensive and less irritating to the skin. Antiseptic solution is quite expensive, can irritate the skin, and have an allergic or toxic side effects. Soap has little value as an antiseptic and relatively inexpensive. Tap water, sterile water, antiseptic solution, normal saline, and water and soap are some solutions that can be us as periuretral cleaning solution. Further study related to the usage of steril water or normal saline is needed.
\end{abstract}

Key words: Indwelling urinary catheter, periurethral cleaning solution, urinary tract infection. 
Awaluddin: Larutan Pembersih Periuretra Sebelum Pemasangan Kateter Urin Menetap

\section{Pendahuluan}

Saat ini kejadian infeksi nosokomial menjadi perhatian utama bagi pelayanan kesehatan, karena angka kejadian infeksi tersebut cukup tinggi terutama infeksi saluran kemih (ISK). Infeksi nosokomial tersebut telah menjadi topik utama yang dipilih pada tantangan keselamatan pasien global (National Health and Medical Research Council [NHMRC], 2010 \& WHO, 2005). Infeksi nosokomial yang sering terjadi menurut World Health Organization (WHO) (2005) adalah ISK. Angka kejadian ISK nosokomial ini sesuai dengan laporan 80 rumah sakit pada sistem National Nosocomial Infection Surveillance (NNIS) dari tahun 1990-1992 adalah 33,1\% (Emori \& Gaynes, 1993). Pada tahun 2002, angka kejadian ISK ini meningkat menjadi $36 \%$ (Klevens, dkk., 2007). Kalsi, Arya, Wilson, dan Mundy (2003) juga menemukan bahwa angka kejadian ISK sebanyak $40 \%$ dari seluruh infeksi nosokomial. Angka kejadian ISK nosokomial ini di rumah sakit Amerika Serikat adalah sebanyak $42 \%$ dari keseluruhan infeksi nosokomial (Haley, Culver, White, Morgan, \& Emori, 1985) dan di Inggris ISK merupakan kelompok kedua terbesar dengan jumlah sekitar 20\% dari keseluruhan infeksi yang didapatkan di rumah sakit (Madeo \& Roodhouse, 2009). Kejadian infeksi saluran kemih tersebut salah satunya dapat terjadi karena pemasangan kateter urin menetap.

Peningkatan angka penggunaan kateter urin menetap di rumah sakit disertai juga dengan peningkatan infeksi saluran kemih. Hal ini sesuai dengan pendapat WHO (2005), yang menyatakan bahwa infeksi saluran kemih biasanya diakibatkan oleh kateterisasi urin. Penggunaan kateter urin sangat banyak. Terdapat jutaan kateter uretra yang digunakan setiap tahun. Madeo dan Roodhouse (2009) masing-masing menemukan jumlah tindakan kateterisasi ini pada perawatan akut adalah 26,3\% dan 31\%. Sementara Hazelett, Tsai, Gareri, dan Allen (2006) dalam penelitiannya menemukan bahwa dalam setiap bulannya terdapat sebanyak 23,2\% (379 dari 1.633) pasien yang terpasang kateter urin menetap.

Kejadian ISK akibat pemasangan kateter urin menetap cukup tinggi. Sepuluh sampai $30 \%$ dari pasien yang terpasang kateter urin menetap jangka pendek akan berkembang menjadi bacteriuria (Madeo \& Roodhouse, 2009). Pada kateter menetap jangka pendek atau jangka panjang ini, angka infeksi adalah $3-5 \%$, 5\%, dan $3-10 \%$ per harinya (Lawal, 2012 \& Nicolle, 2014). Crow, Mulhall, dan Chapman (1988) melakukan juga penelitian prospektif pada 220 pasien rawat inap dengan hasil bacteriuria ditemukan pada 97 (44\%) pasien. Lawal (2012) menemukan bahwa angka kejadian ISK yang disebabkan oleh kateter urin menetap adalah $10,2-15,2 \%$ dan $80 \%$.

Angka kejadian ISK nosokomial akibat pemasangan kateter urin menetap di beberapa rumah sakit di Indonesia juga cukup tinggi. Fitriani (2007) menemukan angka kejadian ISK nosokomial pada pasien yang terpasang kateter urin lebih dari 3 hari di RSUD Pandan Arang Boyolali adalah 60,42\% (29 dari 48). Penelitian Nurokhim (2001) juga menemukan bahwa angka kejadian bacteriuria terjadi pada pasien yang telah terpasang kateter urin menetap selama 1-5 hari di bagian obstetri dan ginekologi RSUP Dr. Kariadi Semarang sebanyak 38,14\% (37 dari 97). Angka kejadian ISK nosokomial di RS Roemani Semarang yaitu sebanyak 36,7\% (11 dari 30) (Kasmad, Sujianto, \& Hidayati, 2007). Angka kejadian ISK nosokomial akibat pemasangan kateter urin menetap di RSU Raden Mattaher Jambi sebanyak 23,91\% (11 dari 46) (Sepalanita, 2012). Rarung (2008) pun menemukan angka kejadian ISK pada pasien setelah sectio caesarea di instalasi bedah sentral dan kamar bedah obstetri RSU Prof. Dr. R. D. Kandou Manado sebesar 20\% (20 dari 100). Marlina dan Samad (2013) menemukan angka kejadian ISK nosokomial di ruang penyakit dalam RSUD dr. Zainoel Abidin Banda Aceh sebanyak 11,42\% (4 dari 35). Kejadian ISK tersebut akan berdampak terhadap hal-hal yang juga dapat merugikan pasien.

Dampak kejadian ISK dapat merupakan suatu ancaman bagi terganggunya kesehatan fisik ringan bahkan sampai dengan berat. Hal ini sesuai dengan pendapat Emmersoneia bahwa ISK nosokomial akan meningkatkan angka kesakitan dan kematian (Madeo \& Roodhouse, 2009). Platt, Polk, Murdock, dan Rosner (1982) menemukan bahwa kematian akibat ISK adalah tiga kali lipat diantara pasien rawat inap, dengan jumlah kematian 
di rumah sakit di Amerika Serikat adalah sebanyak 13,2\% (13.088 dari 98.987 kasus infeksi nosokomial keseluruhan) pada tahun 2002 (Klevens, dkk., 2007). Angka kematian akibat ISK dapat diturunkan apabila tenaga kesehatan memahami proses terjadinya ISK.

Proses terjadinya ISK salah satunya dapat terjadi pada pemasangan kateter urin menetap. Kateter memungkinkan naiknya organisme normal pada area periuretra baik melalui permukaan ekstraluminal atau pun intraluminal (Nicolle, 2014). Kontaminasi ekstraluminal ini dapat terjadi lebih awal, organisme dapat masuk langsung saat kateter dimasukkan, atau kemudian, oleh organisme yang naik dari perineum ke permukaan kateter eksternal (Maki \& Tambyah, 2001). Hal ini terutama terjadi pada pasien yang pembersihan perineum dan distal uretranya tidak memadai (Tenke, dkk., 2008). Sebagian besar mikroorganisme penyebab ISK berasal dari flora kolon dan perineum pasien sendiri atau dari tangan petugas kesehatan selama pemasangan kateter atau manipulasi dari sistem kantung drainase (Maki \& Tambyah, 2001). Kemampuan membatasi komplikasi akan berkurang jika sudah terjadi bacteriuria Apabila organisme tersebut sudah masuk dan bacteriuria berkembang, kemampuan untuk membatasi komplikasi ini menjadi minimal. Intervensi yang tepat pada pembersihan area periuretra sebelum pemasangan kateter menjadi sangat penting dalam mencegah ISK ini.

Perawat memiliki peran dalam mencegah terjadinya risiko ISK nosokomial ini melalui praktik pengontrolan infeksi dengan cara yang tepat dan penggunaan teknologi modern (Pittet, Allegranzi, Stor, \& Donaldson, 2006; Wilson, dkk., 2009). Perawat melakukan pemasangan kateter ini pada lebih dari $50 \%$ pasien yang terpasang kateter urin dari seluruh pemasangan kateter urin yang dilakukan (Crow, dkk., 1988 \& Madeo; Roodhouse, 2009). Intervensi keperawatan seharusnya didukung oleh bukti praktik yang terbaik untuk membantu meminimalisasi potensial terjadinya risiko pada pasien (Madeo \& Roodhouse, 2009). Pemahaman perawat mengenai larutan pembersih area periuretra sebelum pemasangan kateter dan perawatan kateter menetap sangat penting dalam mencegah terjadinya ISK.

Pada penjelasan latar belakang di atas, maka perlu dilakukannya tinjauan liretature review mengenai larutan pembersih area periuretra sebelum pemasangan kateter urin menetap dan pengaruhnya terhadap kejadian ISK. Literature review ini bertujuan untuk mengidentifikasi larutan pembersih periuretra yang digunakan sebelum pemasangan kateter urin menetap.

\section{Metode Penelitian}

Metode yang digunakan dalam tulisan ini adalah literature review. Pencarian dilakukan antara lain pada database CINAHL, proquest, dan google scholar yang dipublikasikan dari tahun 1995 sampai dengan tahun 2013. Kata kunci yang digunakan dalam literature review ini yaitu catheterization, indwelling urinary catheter, bacteriuria, meatal, atau periurethral cleaning, urinary tract infection, dan nursing. Terdapat sejumlah 102 artikel yang ditemukan sesuai dengan kata kunci tersebut. Setelah artikel tersebut dievaluasi sesuai kriteria, yaitu larutan atau antiseptik yang digunakan sebelum pemasangan kateter urin menetap, didapatkan sejumlah 25 artikel yang ditelaah untuk di-review. Teori lain juga digunakan dalam literature review ini untuk memperkuat alasan dari literatur yang dikaji.

\section{Hasil Penelitian}

Dua puluh lima artikel disintesis menjadi enam jenis larutan: air kran, air steril,

Tabel 1 Jenis Larutan dan Antiseptik sebagai Pembersih sebelum Pemasangan Kateter Menetap

\begin{tabular}{ccl}
\hline \multicolumn{1}{c}{ Peneliti } & Larutan atau antiseptik & \multicolumn{1}{c}{ Hasil } \\
\hline Nasiriani dkk., 2009 & Air kran dan povidone iodine & $\begin{array}{l}\text { Air kran=povidone iodine terjadi } \\
16,7-20 \% \text { bacteriuria }\end{array}$ \\
Al-Farisi dkk., 2009 & Air steril dan povidone iodine 10\% & $\begin{array}{l}\text { Air steril=povidone iodine 10\% } \\
\text { terjadi 16-18\% bacteriuria }\end{array}$ \\
\hline
\end{tabular}


Awaluddin: Larutan Pembersih Periuretra Sebelum Pemasangan Kateter Urin Menetap

\begin{tabular}{|c|c|c|}
\hline Peneliti & Larutan atau antiseptik & Hasil \\
\hline Cheung dkk., 2008 & $\begin{array}{l}\text { Chlorhexidine gluconate }(\mathrm{CHG}) \\
0.05 \% \text { dan air steril }\end{array}$ & $\begin{array}{l}\text { Chlorhexidine gluconate (CHG) } \\
0.05 \%=\text { air steril tidak ada terjadi } \\
\text { bacteriuria simptomatik }\end{array}$ \\
\hline Webster dkk., 2001 & $\begin{array}{l}\text { Air dibandingkan dengan } \\
\text { chlorhexidine } 0.1 \%\end{array}$ & $\begin{array}{l}\text { Air }=\text { chlorhexidine } 0.1 \% \text { terjadi } \\
8,2-9,2 \% \text { terjadi bacteriuria }\end{array}$ \\
\hline Jeong dkk., 2010 & $\begin{array}{l}\text { Air dan sabun, busa pembersih } \\
\text { kulit, povidone iodine } 10 \% \text { dan } \\
\text { salin normal. }\end{array}$ & $\begin{array}{l}\text { Air dan sabun=busa pembersih } \\
\text { kulit }=\text { povidone iodine } 10 \%=\text { salin } \\
\text { normal dengan kejadian insiden } \\
\text { kumulatif ISK } 1,96-4,18 \text {. }\end{array}$ \\
\hline
\end{tabular}

larutan antiseptik, salin normal, air sabun, dan busa pembersih kulit sesuai tabel 1 . Healthcare Infection Control Practices Advisory Committee (HICPAC) (2009) ini merekomendasikan penggunaan antiseptik atau larutan steril yang sesuai untuk membersihkan daerah atau area periuretra sebelum dilakukannya pemasangan kateter (Gould, dkk., 2010).

Penelitian-penelitian tentang penggunaan air steril atau air kran dan larutan antiseptik telah dilakukan. Penelitian Nasiriani, dkk. (2009) dilakukan dalam membandingkan angka kejadian bacteriuria dan infeksi saluran kemih ketika air kran dan larutan povidone iodine digunakan pada saat membersihkan periuretra pasien wanita yang akan dipasang kateter sebelum pembedahan ginekologi. Hasil penelitian setelah 24 jam dilakukannya pemasangan kateter ini menunjukkan bahwa secara keseluruhan, 18,3\% dari 60 subjek mengalami bacteriuria saat kateter dilepas. Secara statistik tidak terdapat perbedaan yang signifikan kejadian bacteriuria yaitu $20 \%$ pada kelompok yang dibersihkan dengan air kran dan $16,7 \%$ pada kelompok povidone iodine. Penelitian tersebut juga melaporkan adanya efek samping. Risiko reaksi efek samping penggunaan agen antiseptik ini tidak umum, namun pernah terjadi. Selain itu, terdapat penambahan biaya terkait dengan penggunaan antiseptik ini.

Penelitian randomized control trial (RCT) yang telah dilakukan oleh Al-Farsi, Oliva, Davidson, Richardson, dan Ratnapalan (2009) membandingkan angka ISK pada anak yang akan dilakukan kateterisasi yang dilakukan pembersihan periuretra dengan air steril dan povidone iodine $10 \%$. Kelompok air steril berjumlah 92 pasien dan povidone iodine $10 \%$ pada 94 pasien. Hasil penelitian menunjukkan urin kultur positif pada 16\% responden, 15
(16\%) pada kelompok yang mendapatkan povidone iodine $10 \%$ dan $18 \%$ responden 17 (18\%) pada kelompok yang mendapatkan air steril. Tidak ada perbedaan yang signifikan pada tanda dan gejala pada kedua kelompok. Pembersihan periuretra pada anak dengan air steril sebelum pemasangan kateter tidak lebih rendah daripada povidone iodine. Hasil penelitian ini menunjukkan bahwa air steril tidak lebih buruk dari larutan antiseptik sebagai larutan pembersih periuretra pada anak. Air steril selalu tersedia, tidak mahal, dan memiliki efek samping yang minimal dan tidak mengiritasi kulit (Sanders, 2009).

Penelitian RCT yang telah dilakukan oleh Cheung, dkk., (2008) juga membandingkan risiko terjadinya ISK simptomatisk melalui praktik konvensional dengan menggunakan chlorhexidine gluconate (CHG) $0.05 \%$ dengan menggunakan air steril untuk membersihkan periuretra sebelum pemasangan kateter urin menetap pada pasien di rumah perawatan. Spesimen urin untuk kultur diambil empat kali untuk setiap subjek dalam dua minggu pada sebanyak 74 sampel yang diambil dari 20 subjek (delapan pada kelompok air steril dan 12 pada kelompok CHG 0.05\%). Hasil penelitian tersebut menunjukkan bahwa tidak terdapat perbedaan yang signifikan dalam kolonisasi bakteri antara kedua kelompok. dan tidak ada subjek pada kedua kelompok yang mengalami bacteriuria simptomatik. Penelitian tersebut menyimpulkan bahwa penggunaan air steril untuk membersihkan area periuretra sebelum kateterisasi tidak meningkatkan risiko ISK.

Penelitian RCT yang juga dilakukan oleh Webster, dkk., (2001) membandingkan angka kolonisasi urin pada subjek yang dilakukan pembersihan area periuretra antara sebelum pemasangan kateter urin menetap dengan menggunakan air yang dibandingkan dengan 
chlorhexidine $0.1 \%$ pada pasien obstetri. Spesimen urin dikumpulkan dalam 24 jam setelah pemasangan kateter. Hasil penelitian menunjukkan bahwa dari 436 pasien (219 kelompok air dan 217 kelompok antiseptik) mendapatkan sejumlah 38 responden $(8,7 \%)$ mengalami backteriuria $>106 \mathrm{cfu} / \mathrm{L}$. Angka kejadian ISK pun sama antara kedua kelompok (kelompok air 8,2\% dan kelompok antiseptik 9,2\%; OR 1,13; CI 95\%). Penelitian ini menyimpulkan bahwa praktik pembersihan periuretra dengan menggunakan antiseptik tidak menurunkan angka bacteriuria dan mungkin tidak bermanfaat.

\section{Hasil Penelitian}

Dua puluh lima artikel disintesis menjadi enam jenis larutan, yaitu: air kran, air steril, larutan antiseptik, salin normal, air sabun, dan busa pembersih kulit sesuai tang dapat dilihat pada tabel 1. HICPAC (2009) merekomendasikan penggunaan antiseptik atau larutan steril yang sesuai untuk membersihkan area periuretra sebelum pemasangan kateter (Gould, dkk., 2010).

Beberapa hasil penelitian mengenai penggunaan air steril atau air kran dan larutan antiseptik telah dilakukan. Nasiriani, dkk. (2009) melakukan penelitian yang bertujuan untuk membandingkan angka bacteriuria dan infeksi saluran kemih ketika air kran dan larutan povidone iodine digunakan untuk membersihkan area periuretra pada pasien wanita yang akan dipasang kateter sebelum dilakukan pembedahan ginekologi. Hasil penelitian setelah 24 jam pemasangan kateter menunjukkan secara keseluruhan bahwa $18,3 \%$ dari 60 subjek mengalami bacteriuria saat kateter dilepas. Secara statistik tidak terdapat perbedaan yang signifikan kejadian bacteriuria yaitu $20 \%$ pada kelompok yang dibersihkan dengan air kran dan 16,7\% pada kelompok povidone iodine. Meskipun risiko reaksi efek samping penggunaan agen antiseptik tidak umum, namun pernah terjadi. Selain itu, terdapat juga penambahan biaya terkait dengan penggunaan antiseptik ini.

Penelitian yang dilakukan oleh RCT AlFarsi, dkk. (2009) membandingkan angka ISK pada anak yang akan dilakukan kateterisasi yang dilakukan untuk pembersihan periuretra dengan air steril dan povidone iodine 10\%. Kelompok air steril berjumlah 92 pasien dan povidone iodine $10 \%$ pada 94 pasien. Hasil penelitian menunjukkan urin kultur positif pada $15(16 \%)$ pada kelompok povidone iodine $10 \%$ dan $17(18 \%)$ pada kelompok air steril. Tidak ada perbedaan yang signifikan pada tanda dan gejala pada kedua kelompok. Pembersihan area periuretra pada anak dengan air steril sebelum pemasangan kateter tidak lebih rendah daripada povidone iodine. Hasil penelitian ini menunjukkan bahwa air steril tidak lebih buruk dari larutan antiseptik sebagai larutan pembersih periuretra pada anak. Air steril selalu tersedia, tidak mahal dan memiliki efek samping yang minimal dan tidak mengiritasi kulit (Sanders, 2009).

Penelitian RCT Cheung, dkk., (2008) membandingkan risiko mendapatkan ISK simptomatik melalui praktik konvensional menggunakanchlorhexidinegluconate $(\mathrm{CHG})$ $0.05 \%$ dengan air steril untuk membersihkan periuretra sebelum pemasangan kateter urin menetap pada pasien di rumah perawatan. Spesimen urin untuk kultur diambil empat kali untuk setiap subjek dalam duan minggu pada 74 sampel yang diambil dari 20 subjek (delapan pada kelompok air steril dan 12 pada kelompok CHG 0.05\%). Hasil penelitian ini menunjukkan bahwa tidak ada perbedaan kolonisasi yang signifikan antara kedua kelompok dan tidak ada subjek pada kedua kelompok ini yang mengalami bacteriuria simptomatik. Penelitian ini menyimpulkan bahwa penggunaan air steril untuk membersihkan area periuretra sebelum kateterisasi tidak meningkatkan risiko ISK.

Penelitian RCT Webster, dkk., (2001) membandingkan angka kolonisasi urin pada subjek yang dilakukan pembersihan area periuretra sebelum pemasangan kateter urin menetap dengan air dibandingkan dengan chlorhexidine $0.1 \%$ pada pasien obstetri. Spesimen urin dikumpulkan 24 jam setelah pemasangan kateter. Hasil penelitian dari 436 pasien (219 kelompok air dan 217 kelompok antiseptik), 38 (8,7\%) mengalami bacteriuria $>106 \mathrm{cfu} / \mathrm{L}$. Angka kejadian ISK sama antara kedua kelompok (kelompok air 8,2\% dan kelompok antiseptik 9,2\%; OR 1,13; \& CI 95\%). Penelitian ini menyimpulkan 
Awaluddin: Larutan Pembersih Periuretra Sebelum Pemasangan Kateter Urin Menetap

bahwa praktik pembersihan area periuretra dengan antiseptik tidak menurunkan angka bacteriuria dan mungkin tidak bermanfaat.

\section{Pembahasan}

Perawat sebagai salah satu tenaga kesehatan yang sering melakukan tindakan pemasangan kateter urin menetap, maka perlu memahami pentingnya untuk dilakukan pembersihan area periuretra sebelum pemasangan kateter urin menetap. Pembersihan area periuretra dapat menurunkan populasi bakteri. Hal ini dapat dilihat dari penelitian Kehinde, dkk. (2008) yang melakukan penelitian tentang flora bakteri pada perineum sebelum dan sesudah diberi antiseptik campuran chlorhexidinecetrimide pada 114 pasien laki-laki yang akan dilakukan prosedur sistoskopi. Hasil penelitiannya adalah ditemukan 43 (37\%) kultur positif sebelum dan $7(6,1 \%)$ setelah diberikan chlorhexidine-cetrimide serta 13 $(11,4 \%)$ setelah prosedur sistoskopi. Hasil penelitian tersebut menunjukkan bahwa setelah membersihkan area periuretra maka populasi bakteri dapat diturunkan. Dengan demikian jika area periuretra dibersihkan sebelum pemasangan kateter urin maka saat memasukkan kateter melalui uretra maka bakteri tidak akan masuk ke kandung kemih sehingga kejadian ISK dapat dicegah atau diminimalisasi.

Pembersihan area periuretra ini dapat dilakukan dengan berbagai macam larutan yang juga memiliki efek antiseptik. Larutan yang pertama adalah air steril. Penggunaan air steril sebagai larutan pembersih area periuretra sebelum pemasangan kateter urin menetap mungkin memiliki alasan bahwa air steril merupakan larutan hipotonik. Bakteri yang berada di lingkungan larutan hipotonik maka bakteri akan mengalami plasmoptisis yaitu pecahnya sel bakteri karena air akan masuk ke dalam sel bakteri (Melliawati, 2009; Stranz \& Kastango, 2002). Dengan demikian bakteri akan mati.

Larutan kedua adalah antiseptik (povidone iodine 10\%). Povidoneiodine merupakansuatu antiseptik yang sering digunakan. Beberapa definisi dari antiseptik lebih menekankan efek menghambat (bakteriostatik) daripada efek merusak atau membunuh (disinfeksi atau bakterisida) (McKenry, Tessier, \& Hogan, 2006; Melliawati, 2009). Antiseptik biasanya digunakan hanya untuk jaringan yang hidup (berbeda dengan disinfektan). Antiseptik kurang kuat dibandingkan disinfektan atau lebih encer yang dilakukan untuk mencegah kerusakan pada sel. Berkurangnya kekuatan, meskipun penting untuk jaringan hidup tentunya hal ini akan mengurangi efektivitas antiseptik (McKenry, dkk., 2006).

Iodine merupakan salah satu antiseptik yang efektif dan efisien saat ini (McKenry, dkk., 2006; Tortora, Funke \& Case, 2007). Unsur iodine memiliki efek bakterisidal, virisidal, fungisidal, dan mematikan bagi protozoa, namun kurang efektif terhadap spora (McKenry, dkk., 2006; Tortora, dkk., 2007) dan tuberkulosidal (Mcdonnell \& Russell, 1999). Molekul iodine lebih bagus daripada antiseptik lain karena semua jenis bakteri dapat dirusak oleh konsentrasi tunggal dari iodine dan efektif pada $\mathrm{pH}$ yang bervariasi. Molekul iodine secara cepat dapat menembus dinding sel pada mikroorganisme dan menonaktifkan sel dengan membentuk kompleks dengan asam amino dan asam lemak tidak jenuh, sehingga mengakibatkan gangguan sintesis protein dan perubahan membran sel (Boyce \& Pittet, 2002 ; Tortora, dkk., 2007).

Iodine diserap melalui kulit dan akan berpengaruh terhadap fungsi tiroid jika digunakan dalam kurun waktu yang lama. Neonatus juga dapat mengalami hipotiroid setelah pemakaian topikal povidone iodine. Reaksi hipersensitivitas sering terjadi yang dimanifestasikan oleh reaksi sistemik berat yaitu demam dan ruam kulit menyeluruh. Efek samping lain dari povidone iodine adalah gatal dan edema lokal (McKenry, dkk., 2006).

Iodine sering menyebabkan iritasi kulit dan larutan iodine juga umumnya tidak stabil. Dalam larutan, setidaknya ada tujuh spesies iodine yang ada di kompleks keseimbangan, dengan molekul iodin (I2) yang terutama bertanggung jawab pada hal keberhasilan antimikrobial (Mcdonnell \& Russell, 1999). Iodofor menggantikan sebagian besar iodine sebagai bahan aktif dalam antiseptik karena akibat iritasi dan tidak stabil tersebut (Boyce 
\& Pittet, 2002). Iodofor merupakan kompleks iodine dan agen pelarut atau carrier, yang bertindak sebagai reservoir aktif iodine 'bebas'. Adanya sejumlah molekul iodine (disebut iodine 'bebas') menentukan tingkat aktivitas antimikroba iodofor (Boyce \& Pittet, 2002).

Penggabungan iodine dengan berbagai polimer dapat meningkatkan kelarutan iodine, meningkatkan juga pelepasan berkelanjutan iodine, dan mengurangi iritasi kulit. Polimer yang paling umum dimasukkan ke iodofor adalah polivinil pirolidon (yaitu, povidone) dan deterjen nonionik teretoksilasi (yaitu, poloxamers) (Boyce \& Pittet, 2002). Iodofor ini juga merupakan suatu kelompok senyawa pada iodine yang dikombinasikan dengan povidone sebagai pembawa (carrier), yang akan meningkatkan daya larut iodine serta akan melepaskan iodine secara lambat (McKenry, dkk., 2006; Tortora, dkk., 2007). Povidone iodine juga merupakan suatu iodofor (McKenry, dkk., 2006). Povidone iodine bekerja dengan merusak protein dan DNA mikroba (McKenry, dkk., 2006).

Sebagian besar iodofor yang digunakan mengandung $7,5 \%-10 \%$ povidone iodine (Berkelman, Holland, \& Anderson, 1982). Formulasi povidone iodine 10\% mengandung $1 \%$ iodine dan hanya menghasilkan $1 \mathrm{ppm}$ konsentrasi iodine bebas (Boyce \& Pittet, 2002). Povidone iodine $10 \%$ merupakan salah satu larutan yang digunakan pada pembersihan area periuretra sebelum pemasangan kateter (Maki \& Tambyah, 2001). Formulasi dengan konsentrasi yang lebih rendah memiliki aktivitas antimikroba yang baik karena pengenceran dapat meningkatkan konsentrasi iodine bebas. Namun, karena jumlah iodine bebas meningkat, tingkat iritasi kulit juga dapat meningkat (Berkelman, dkk., 1982). Iodofor menyebabkan sedikit iritasi kulit dan reaksi alergi lebih sedikit daripada iodine, tetapi dermatitis kontak lebih iritan daripada antiseptik lain (Boyce \& Pittet, 2002).

Povidone iodine efektif dalam melawan banyak bakteri gram positif dan gram negatif serta jamur (Asci \& Beyea, 1996), namun iodine dapat mengakibatkan iritasi kulit (Mcdonnell \& Russell, 1999 \& Boyce \& Pittet, 2002) dan pemakaian povidone iodine pada area periuretra tidak mengurangi risiko ISK (Tietjen, Bossemeyer, \& McIntosh,
2004). Iodine dan povidone iodine 10\% dikarekteristikan dengan kecenderungan terhadap iritasi dan kerusakan kulit, serta efek alergi atau toksik pada orang yang sensitif (Larson \& APIC Guidelines Committee, 1995). Iritasi pada uretra akan menjadi faktor prediposisi masuknya (port de entry) bakteri ke dalam jaringan (Potter \& Perry, 2005). Selain dapat mengiritasi kulit, povidone iodine juga cukup mahal (Jeong, dkk., 2010).

Pendapat ahli juga menunjukkan bahwa tidak ada keuntungan dalam menggunakan sediaan antiseptik dibandingkan salin normal untuk membersihkan meatus uretra sebelum pemasangan kateter (NHMRC, 2010). Hal ini mungkin karena penggunaan agen antiseptik dapat mengiritasi membran mukosa tersebut dan juga dapat mengakibatkan terbakar bahan kimia. Iritasi dapat menjadi jalur masuk bagi bakteri (Potter \& Perry, 2005). Iritasi ini juga dapat menyebabkan nyeri pada pasien dan meningkatkan ketidaknyamanan selama prosedur klinis (Madeo \& Roodhouse, 2009; Sanders, 2009). Conway dan Larson (2012) melakukan evaluasi terhadap delapan panduan untuk pencegahan ISK menemukan bahwa larutan pembersihan meatus lebih efektif dengan antiseptik dibandingkan salin normal steril sebelum pemasangan kateter urin menetap masih kontradiksi. Kontradiksi tersebut muncul mungkin karena efek iritasi oleh antiseptik tersebut.

Larutan ketiga adalah salin normal $(\mathrm{NaCl}$ $0.9 \%$ ). Salin normal dapat digunakan sebagai antiseptik. Salin normal tidak beracun dan tidak menyebabkan iritasi (Alvarez, dkk., 2010). Salin normal juga dapat menyebabkan efek plasmolisis pada bakteri Escherichia coli (Scheie, 1973). Klor dapat merusak bakteri melalui proses oksidasi. Klor di dalam air menyebabkan bebasnya $\mathrm{O}_{2}$ sehingga zat ini dapat membunuh bakteri. Hubungan klor dengan protoplasma pun dapat menimbulkan oksidasi (Melliawati, 2009). Bakteri yang berada pada lingkungan osmolaritas yang lebih rendah yaitu 270-300 mosmol/L, seperti serum manusia atau media bakteriologis biasa, secara intrinsik akan menstabilkan membran sitoplasma bakteri untuk bertahan hidup (Domingue \& Woody, 1997). Hal ini berarti pada larutan $\mathrm{NaCl} 0.9 \%$ yang memiliki osmolaritas $310 \mathrm{mOsm} / \mathrm{L}$ maka bakteri akan rusak karena konsentrasi 
Awaluddin: Larutan Pembersih Periuretra Sebelum Pemasangan Kateter Urin Menetap

hipertonik. $\mathrm{NaCl} 0.9 \%$ juga lebih murah dan kurang mengiritasi kulit (Jeong, dkk., 2010).

Penggunaan salin normal juga pernah diteliti oleh Jeong, dkk., (2010) dengan tujuan penelitian membandingkan angka ISK akibat pemasangan kateter dari penggunaan empat agen perawatan perineum pada pasien dewasa wanita di intensive care unit (ICU). Agen tersebut juga dapat digunakan sebelum pemasangan kateter. Keempat agen tersebut yaitu air dan sabun, busa pembersih kulit (skin cleansing foam), larutan povidone iodine $10 \%$, dan $\mathrm{NaCl} 0.9 \%$. Penelitian eksperimen nonrandom ini dilakukan pada 97 pasien dengan menggunakan air dan sabun $(\mathrm{n}=22)$, busa pembersih kulit $(\mathrm{n}=24)$, larutan povidone iodine $(\mathrm{n}=28)$, dan $\mathrm{NaCl}$ $0.9 \% \quad(n=23)$ yang terpasang kateter lebih dari dua hari di tiga ICU antara bulan AprilJuli 2008. Pasien menerima satu dari empat jenis perawatan perineum. Data insiden ISK dikumpulkan sebelum perawatan perineum dan satu minggu, dua minggu dan empat minggu setelah dimulainya perawatan perineum. Hasil penelitian adalah rata-rata cumulative incidence ISK pada empat agen (sabun dan air, busa pembersih kulit, povidone iodine, dan $\mathrm{NaCl} 0.9 \%$ ) berturut-turut adalah 3,72; 2,65; 4,18; dan 1,96.

Leaver (2007) juga menyatakan bahwa tipe larutan pembersih periuretra sebelum dilakukan pemasangan kateter tidak harus spesifik baik larutan $\mathrm{NaCl} 0.9 \%$, air steril, atau larutan antiseptik adalah sama-sama efektif. Hal yang hampir sama dinyatakan juga oleh Department of Health \& Human Service: Tasmania Infection Prevention \& Control Unit (2010) yang merekomendasikan bahwa penggunaan air steril atau antiseptik untuk membersihkan periuretra sebelum pemasangan kateter. Clinical Nurse Specialist (2013) menyarankan pemakaian $\mathrm{NaCl}$ 0.9\% atau larutan antiseptik untuk membersihkan meatus sebelum pemasangan kateter. Selain itu, disarankan juga untuk membersihkan meatus dengan salin normal steril sebelum pemasangan kateter menetap jangka pendek di tatanan rumah sakit. Hal ini didukung oleh Department of Health and Human Service: Health Protection Scotland (2012) yang merekomendasikan bahwa pembersihan meatus uretra dengan menggunakan salin normal sebelum pemasangan kateter urin menetap. Head (2006) juga menganjurkan penggunaan salin normal sebagai larutan pembersih sebelum pemasangan kateter urin.

Selanjutnya larutan keempat sebagai agen pembersih area periuretra sebelum pemasangan kateter urin menetap adalah antiseptik jenis chlorhexidine. Chlorhexidine merupakan suatu anggota dari kelompok biguanide dengan aktivitas spektrum luas. Chlorhexidine sering digunakan juga untuk mengontrol mikroba pada kulit dan membran mukosa. Chlorhexidine yang dikombinasikan dengan deterjen atau alkohol juga digunakan untuk penggosok tangan sebelumpembedahan dan persiapan kulit sebelum pasien dioperasi. Suatu produk kombinasi dari chlorhexidine dengan alkohol dapat bertahan selama kirakira enam jam. Produk tersebut diakui oleh FDA sebagai waterless \& scrubless antiseptic sebelum pembedahan. Dalam aplikasi tertentu chlorhexidine memiliki toksisitas rendah. Efek membunuh bakteri dari chlorhexidine dapat mencederai membran plasma dengan memblok suatu enzim yang dibutuhkan untuk sintesis lipid. Chlorhexidine adalah biosidal terhadap banyak bakteri vegetatif dan juga jamur. Mikobakteri relatif resisten terhadap chlorhexidine, serta tidak dapat memengaruhi endospora dan protozoa. Virus yang dapat dipengaruhi adalah yang memiliki selubung lipid (lipophilic) (Tortora, dkk., 2007).

Larutan (agen) kelima adalah sabun dan air. Sabun dan air relatif murah, tetapi dapat menyebabkan iritasi kulit atau kerusakan kulit dan kulit menjadi kering jika digunakan terlalu sering (Boyce, Kelliher, \& Vallande, 2000 \& Winnefeld, Richard, Drancourt, \& Grobb, 2000) dan sabun juga dapat menjadi penyebab dari infeksi nosokomial apabila terkontaminasi (Sartor, dkk., 2000). Agen keenam adalah busa pembersih kulit. Busa pembersih kulit lebih mahal dari sabun, tetapi mudah digunakan dan mudah menghilangkan bau dan kontaminan.

Pada hasil review, panduan, dan juga pendapat ahli dapat disimpulkan bahwa tidak terdapat perbedaan efek antara penggunaan larutan $\mathrm{NaCl} 0.9 \%$, antiseptik (povidone iodine $10 \%$, chlorhexidine gluconate $0.05 \%$, dan 1\%), sabun dan air, busa pembersih kulit, atau air steril sebagai agen pembersih area periuretra sebelum pemasangan kateter urin menetap dalam menurunkan risiko 
ISK. Namun terdapat beberapa hal yang mungkin perlu menjadi bahan pertimbangan dalam memutuskan untuk penggunaan jenis larutan pembersih area periuretra sebelum pemasangan kateter urin menetap. $\mathrm{NaCl}$ $0.9 \%$ tidak beracun, tidak mengiritasi kulit dan lebih murah (Alvarez, 2010 \& Jeong, dkk., 2010). Povidone iodine 10\% cukup mahal dan dapat mengiritasi kulit serta lebih iritan daripada antiseptik lain (Jeong, dkk. 2010). Kadang-kadang povidone iodine $10 \%$ juga telah terkontaminasi dengan basil gram negatif sebagai akibat proses produksi yang buruk dan telah menyebabkan infeksi wabah atau wabah semu (Boyce \& Pittet, 2002; Larson \& APIC Guidelines Committee, 1995; \& Mcdonnell \& Russell, 1999). Iritasi pada uretra akan menjadi faktor prediposisi masuknya (port de entry) bakteri ke dalam jaringan (Potter \& Perry, 2005). Sedangkan chlorhexidine memiliki toksisitas rendah (Tortora, dkk., 2007). Sabun dan air relatif murah, tetapi dapat menyebabkan iritasi kulit atau kerusakan kulit dan kulit menjadi kering (Boyce, Kelliher \& Vallande, 2000 \& Winnefeld, dkk., 2000) dan sabun juga dapat menjadi penyebab infeksi nosokomial jika terkontaminasi (Sartor, dkk., 2000). Busa pembersih kulit lebih mahal dari sabun, tetapi mudah digunakan dan mudah menghilangkan bau dan kontaminan. Air steril selalu tersedia, tidak mengiritasi kulit dan tidak mahal (Sanders, 2009).

\section{Simpulan}

Berdasarkan hasil literature review ini dapat disimpulkan bahwa larutan pembersih periuretra sebelum pemasangan kateter yang dapat digunakan adalah air kran, air steril, larutan antiseptik, salin normal, air dan sabun, serta busa pembersih kulit. Air steril adalah larutan hipotonik, tidak mahal, dan tidak mengiritasi kulit. Larutan antiseptik cukup mahal dan dapat mengiritasi kulit memiliki efek samping alergi atau toksik. Salin normal lebih murah dan kurang mengiritasi kulit. Sabun memiliki sedikit kadar antiseptik dan relatif murah. Busa pembersih kulit lebih mahal dari sabun, tetapi mudah digunakan dan mudah menghilangkan bau dan kontaminan.

Sesuai dengan hasil literature review ini, perawat sebagai tenaga kesehatan profesional sebaiknya mempertimbangkan jenis larutan pembersih periuretra yang dapat digunakan sebelum pemasangan kateter urin menetap di pelayanan kesehatan. Selain itu diharapkan dilakukan penelitian tentang penggunaan air steril atau salin normal sebagai pembersih area periuretra sebelum pemasangan kateter menetap dalam menurunkan infeksi saluran kemih.

\section{Daftar Pustaka}

Al-Farsi, S., Oliva, M., Davidson, R., Richardson, S. E., \& Ratnapalan, S. (2009). Periurethral cleaning prior to urinary catheterizationin children:Sterilewaterversus 10\% povidone-iodine. Clin Pediatr, 48(6), 656-660. doi: 10.1177/0009922809332587.

Alvarez, J. A., Macias, J. H., Macias, A. E., Rodriguez, E., Munoz, J. M., \& Mosqueda, J. L. (2010). Povidone-iodine against sodium hypochlorite as skin antiseptics in volunteers. Am J Infect Control, 38(10), 822-5. doi: 10.1016/j.ajic.2010.05.019.

Asci, J. A. \& Beyea, S. C. (1996). Urologic update: Indwelling urinary cathetersan integrative review of the research. Worldviews on Evidence-based Nursing presents the archives of Online Journal of Knowledge Synthesis for Nursing, E3, 6-11. doi: 10.1111/j.1524-475X.1996.00006.x.

Berkelman, R. L., Holland, B. W., \&Anderson, R. L. (1982). Increased bactericidal activity of dilute preparations of povidone-iodine solutions. Journal of Clinical Microbiology, 15(4), 635-639.

Boyce, J. M. \& Pittet, D. (2002). Guideline for hand hygiene in health-care settings: Recommendations of the healthcare infection control practices advisory committee and the HICPAC/SHEA/APIC/IDSA. Hand hygiene task force. Infection Control and Hospital Epidemiology, 23(12), S3-S41.

Boyce, J. M., Kelliher, S., \& Vallande, N. (2000). Skin irritation and dryness associated with two hand-hygiene regimens: Soap-and- 
Awaluddin: Larutan Pembersih Periuretra Sebelum Pemasangan Kateter Urin Menetap

water handwashing versus hand antisepsis with an alcoholic hand gel. Infection Control and Hospital Epidemiology, 21(7), 442-448. doi: 10.1086/501785.

Cheung, K., Leung, P., Wong, Y., To, O., Yeung., \& Y., Chan, M. (2008). Water versus antiseptic periurethral cleansing before catheterization among home care patients: A randomized controlled trial. American Journal of Infection Control, 36(5), 375-380. doi: 10.1016/j.ajic.2007.03.004.

Clinical Nurse Specialist. (2013). Catheter care guidelines 2013. Canterbury District Health Boar. Diakses dari https://www. cdhb.health.nz/Search/Pages/results. aspx? $\mathrm{k}=$ catheter\%20guidelines.

Conway, L. J. \& Larson, E. L. (2012). Guidelines to prevent catheter-associated urinary tract infection: 1980 to 2010 . Heart Lung, 41(3), 271-283. doi: 10.1016/j. hrtlng.2011.08.001.

Crow, R., Mulhall, A., \& Chapman, R. (1988). Indwelling catheterization and related nursing practice. Journal of Advanced Nursing, 13(4),489-495. doi: 10.1111/j.13652648.1988.tb02855.x.

Department of Health and Human Service: Health Protection Scotland. (2012). What are the key infection prevention and control recommendations to inform a urinary catheter insertion quality improvement tool? Diakses dari www.documents.hps.scot.nhs. $\mathrm{uk} / \mathrm{hai} /$ infection-control/evidence-for-carebundles/literature-reviews/urinary-catheterinsertion-review.pdf.

Department of Health \& Human Service: Tasmania Infection Prevention \& Control Unit. (2010). Preventing catheter-associated urinary tract infections: a guide for healthcare workers. Diakses dari http://www.dhhs.tas. gov.au/_data/assets/pdf_file/0008/75716/ Preventing catheter associated urinary tract_infection_guide_A3_size_V1.0.pdf.

Domingue, G. J. \& Woody, H. B. (1997). Bacterial persistence and expression of disease. Clinical Microbiology Reviews,
$10(2), 320-4$.

Emori, T. G. and Gaynes, R. P. (1993). An overview of nosocomial infections, including the role of the microbiology, laboratory. Clin Microbiol Rev, 6(4), 428-442. doi: 10.1128/ CMR.6.4.428.

Fitriani, I. N. (2007). Pola resistensi kuman Escherichia coli dan Klebsiella sp. pada infeksi saluran kemih di RSUD Pandan Arang Boyolali. (Skripsi). FK UNS.

Gould, C. V., Umscheid, C. A., Agarwal, R. K., Kuntz, G., Pegues, D.A., \& Healthcare Infection Control Practices Advisory Committee (HICPAC). (2010). Guideline for prevention of catheter-associated urinary tract infections 2009. Infection control and hospital epidemiology, 31(4), 319-26. doi: 10.1086/651091.

Haley, R. W., Culver, D. H., White, J. W., Morgan, W. M., \& Emori, T. G. (1985). The nationwide nosocomial infection rate: A new need for vital statistics. Am J Epidemiol, 121(2),159-67.

Hazelett, S. E., Tsai, M., Gareri, M., \& Allen, K. (2006). The association between indwelling urinary catheter use in the elderly and urinary tract infection in acute care. $B M C$ Geriatrics, 6, 15. doi:10.1186/1471-2318-615.

Head, C. (2006). Insertion of a urinary catheter. Nursing Older People, 18(10), 336. Diakses dari http://search.proquest.com/do cview $/ 218603577$ ? accountid $=48290$

Jeong, I., Park, S., Jeong, J. S., Kim, D. S., Choi, Y. S., Lee, Y. S., \& Park, Y.M. (2010). Comparison of catheter-associated urinary tract infection rates by perineal aare Agents in intensive care units. Asian Nursing Research, $4(3), 142-150$.

Kalsi, J., Arya, M., Wilson, P., \& Mundy, A. (2003). Hospital-acquired urinary tract infection. International Journal of Clinical Practice, 57(5), 388-391.

Kasmad, Sujianto, U., \& Hidayati, W. (2007). 
Awaluddin: Larutan Pembersih Periuretra Sebelum Pemasangan Kateter Urin Menetap

Hubungan antara kualitas perawatan kateter dengan kejadian infeksi nosokomial saluran kemih. (Skripsi). PSIK FK UNDIP.

Kehinde, E. O., Ali, Y., Khodakhast, F., Jamal, W. Y., Seshah, M., \& Rotimi, V. O. (2008). A Study of the bacterial flora before and after antiseptic skin preparation of the perineum in male urology patients. Urol Int, 81, 403-408. doi: 10.1159/000167837.

Klevens, R. M., Edwards, J. R., Richards, C. L., Horan, T. C., Gaynes, R. P., \& Pollock, D. A. (2007). Estimating health care-associated infections and deaths in U.S. hospitals. Public Health Reports, 122, 160-6.

Larson, E. L. \& APIC Guidelines Committee. (1995). APIC guideline for handwashing and hand antisepsis in health care settings. Washington, DC: The Association for Professionals in Infection Control and Epidemiology, Inc.

Lawal, K. (2012). Asymptomatic and symptomatic urinary tract infections: Magnitude, special settings and diagnostic testing. Continuing Education Topics \& Issues, 392, 88-91.

Leaver, R. B. (2007). The evidence for urethral meatal cleansing. Nursing Standard, 21(41), 39-42.

Madeo, M., \& Roodhouse, A. J. (2009). Reducing the risks associated with urinary catheters. Nursing Standard, 23(29), 47-55.

Maki, D. G. \& Tambyah, P. A. (2001). Engineering out the risk for infection with urinary catheters. Emerging Infect Dis, 7(2), 342-7.

Marlina \& Samad, R. A. (2013). Hubungan pemasangan kateter dengan kejadian infeksi saluran kemih pada pasien di ruang rawat inap penyakit dalam RSUDZA Banda Aceh tahun 2012. Jurnal Keperawatan Medikal Bedah, 1(1), 35-47.

McDonnell, G. \& Russell, A.D. (1999). Antiseptics and disinfectants: activity, action, and resistance. Clin Microbiol Rev, 12(1), 147-179.

McKenry, L., Tessier, E., \& Hogan, M. (2006). Mosby's pharmacology in nursing (22th Ed.). United States of America: Mosby Inc.

Melliawati, R. (2009). Escherichia coli dalam kehidupan manusia. BioTrends, 4(1), 10-14.

Mulhall, A. B., Chapman, R. G., \& Crow, R. A. (1988). Bacteriuria during indwelling urethral catheterization. J Hosp Infect, 11(3), 253-62.

Nasiriani, K., Kalani, Z., Farnia, F., Motavasslian, M., Nasiriani, F., \& Engberg, S. (2009). Comparison of the effect of water vs. povidone-iodine solution for periurethral cleaning in women requiring an indwelling catheter prior to gynecologic surgery. Urologic Nursing, 29(2), 118-21.

NHMRC (National Health and Medical Research Council) (2010). Australian guidelines for the prevention and control of infection in healthcare. Commonwealth of Australia. Diakses dari http://www.nhmrc. gov.au/guidelines/publications/cd33.

Nicolle, L. E. (2014). Catheter-related urinary tract infection: practical management in the elderly. Drugs \& Aging, 31(1), 1-10. doi: 10.1007/s40266-013-0089-5.

Nurokhim, A. (2001). Pasca pemasangan kateter menetap pada operasi obstetric dan ginekologi. (Tesis). PPDS I FK UNDIP.

Pittet, D., Allegranzi, B., Storr, J., \& Donaldson, L. (2006). 'Clean care is safer care': the global patient safety challenge 2005-2006. International Journal of Infectious Diseases, 10, 419-424. doi: 10.1016/j.ijid.2006.06.001.

Platt, R., Polk, B. F., Murdock, B., \& Rosner, B. (1982). Mortality associated with nosocomial urinary tract infection. New England Journal of Medicine, 307(11), 637642. doi: 10.1056/NEJM198209093071101. 
Awaluddin: Larutan Pembersih Periuretra Sebelum Pemasangan Kateter Urin Menetap

Potter, P. A. \& Perry, A. G. (2005). Buku ajar fundamental keperawatan : konsep, proses, dan praktik. Terjemahan Renata Komalasari., Dian Evriyani., Enie Novieastari, Alfrina Hany \& Sari Kurnianingsih; editor Monica Ester., Devi Yulianti,. \& Intan Parulian. Edisi Keempat. Jakarta: EGC.

Rarung, M.(2008).Perbandingan pemasangan kateter menetap selama 12 dan 24 jam pasca seksio sesarea pada pencegahan retensio urin dan resiko infeksi saluran kemih. JKM. $8(1)$, $45-51$.

Sanders, C. (2009). Comparing periurethral cleansing solution in paediatrics. Paediatric Nursing, 21(7), 11.

Sartor, C., Jacomo, V., Duvivier, C., TissotDupont, H., Sambuc, R., \& Drancourt, M. (2000). Nosocomial serratia marcescens infections associated with extrinsic contamination of a liquid nonmedicated soap. Infection Control and Hospital Epidemiology, 21(3), 196-199. doi : 10.1086/501743.

Scheie, P. (1973). Osmotic pressure in Escherichia coli as rendered detectable by lysozyme attack. Journal of Bacteriology, 114(2), 549-555.

Sepalanita, W. (2012). Pengaruh perawatan kateter urin indwelling model American Association of Critical Care Nurses (AACN) terhadap bakteriuria di RSU Raden Mattaher Jambi. (Tesis). FIK UI .

Stranz, M. \& Kastango, E. S. (2002). A review of $\mathrm{pH}$ and osmolarity. International Journal of Pharmaceutical Compounding, 6(3), 216-20.

Tenke, P., Kovacs, B., Johansen, T. E. B., Matsumoto, T., Tambyah, P. A., \& Naber, K. G. (2008). European and Asian guidelines on management and prevention of catheter-associated urinary tract infections.
International Journal of Antimicrobial Agents, 31S, S68-S7. doi: 10.1016/j. ijantimicag.2007.07.033.

Tietjen, L., Bossemeyer, D., \& McIntosh (2004). Panduan pencegahan infeksi untuk fasilitas pelayanan kesehatan dengan sumber daya terbatas. Jakarta: Yayasan Bina Pustaka Sarwono Prawirohardjo bekerjasama dengan JNPKKR \& JHPIEGO (Porgram MNH \& STARH).

Tortora, G. J., Funke, B. R., \& Case, C. L. (2007). Microbiology an introduction. (9th Ed.). USA: Pearson Education, Inc.

Webster, J., Hood, R. H., Burridge, C. A., Doidge, M. L., Phillips, K. M., \& George, N. (2001). Water or antiseptic for periurethral cleaning before urinary catheterization: A randomized controlled trial. American Journal of Infection Control, 29(6), 389-394. doi:10.1067/mic.2001.117447.

Wilson, M., Wilde, M., Webb, M. L., Thompson, D., Parker, D., Harwood, J., Callan, L., \& Gray, M. (2009). Nursing interventions to reduce the risk of catheterassociated urinary tract infection: Part 2: Staff education, monitoring, and care techniques. $J$ Wound Ostomy Continence Nurs, 36(2), 137-54. doi: 10.1097/01. WON.0000347655.56851.04.

Winnefeld, M., Richard, M.A., Drancourt, M.,\& Grobb, J. J. (2000). Skin tolerance and effectiveness of two hand decontamination procedures in everyday hospital use. The British Journal of Dermatology, 143(3), 546550. doi: 10.1111/j.1365-2133.2000.03708.x.

World Health Organization. (2005). The global patient safety challenge 2005-2006 "clean care is safer care". Geneva: World Health Organization 2005. Diakses dari http://www.who.int/patientsafety/ events/05/ GPSC Launch ENGLISH FINAL.pdf. 